\title{
The Potential Role of Inhalation Therapy Equipment in Nosocomial Pulmonary Infection *
}

\author{
James Allen Reinarz, $\dagger$ Alan K. Pierce, $\$$ Benita B. Mays, and \\ JAY P. SANFord $\S$ \\ (From the Department of Internal Medicine, The University of Texas Southwestern Medical \\ School, Dallas, Texas)
}

Gram-negative bacillary infections are becoming increasingly important in nosocomial disease. These organisms have surpassed staphylococci as causes of infection in hospitalized patients in both frequency and severity (1). Gram-negative urinary tract infections and attendant bacteremia have received considerable attention $(2,3)$. In addition, gram-negative bacillary necrotizing pneumonias have been observed with increasing frequency (4).

Autopsy material at Parkland Memorial Hospital from the years 1952, 1957, and 1963 was reviewed to determine the frequency of necrotizing pneumonia (5). These years were selected to represent a period before the widespread use of present inhalation therapy techniques, a period preceding the introduction of prolonged nebulization treatments, and the present period of widespread use of inhalation therapy. Other predisposing factors had been in extensive usage by the earlier periods, specifically broad-spectrum antibiotics by 1952 and corticosteroids by 1957 . The frequency of gram-negative necrotizing bacillary pneumonia in 1952 was $0.8 \%$, in 1957 was $1.8 \%$, but by 1963 had risen to $8.0 \%\left(\chi^{2} 36.8, \mathrm{p}<\right.$

\footnotetext{
* Submitted for publication October 1, 1964; accepted January 21, 1965.

Presented in part before the 19th annual meeting of the Southern Society for Clinical Investigation, New Orleans, La., January 23, 1965.

The views expressed herein are those of the authors and do not necessarily reflect the views of the U. S. Air Force or the Department of Defense.

†These studies were performed under U. S. Public Health Service training grant T1-A1-30 of the National Institute of Allergy and Infectious Diseases.

$\ddagger$ These studies were performed under U. S. Public Health Service postdoctoral fellowship HPD-17528.

$\S$ Address requests for reprints to Dr. Jay P. Sanford, Department of Internal Medicine, University of Texas Southwestern Medical School, Dallas, Texas.
}

0.001). The association between the increasing incidence of gram-negative necrotizing bacillary pneumonia and widespread use of inhalation therapy coupled with apparent lack of association with other predisposing factors suggested the potential role of inhalation therapy in nosocomial pulmonary infection.

The sequential objectives of this study were to determine the following: 1) Does inhalation therapy equipment deliver significant numbers of viable bacteria as an aerosol? 2) If organisms are aerosolized, what is the frequency and degree of contamination and what organisms are involved? 3) Is the problem of contaminated aerosols comparable at different hospitals? 4) Does some element common to all inhalation equipment act as a source of organisms? 5) Is it possible to reduce the bacterial content of aerosols generated by this equipment to that of ambient air?

\section{Methods}

Inhalation therapy equipment. Most types of inhalation therapy equipment in current use in six major hospitals were studied. These studies do not constitute an attempt either to endorse or to condemn any specific make or model of equipment. The equipment sampled consisted of Bird Mark VII and Mark VIII respirators with and without mainstream reservoir nebulizers, 1 Bennett PV-1, PV-2, PR-1, and PR-2 respirators with and without mainstream reservoir nebulizers, ${ }^{2}$ Dotco respirators, ${ }^{8}$ Puritan nebulizers, ${ }^{4}$ and Mistogen nebulizers. ${ }^{5}$

Inhalation therapy equipment may deliver either $100 \%$ oxygen, compressed air, or a combination of $100 \%$ oxygen and ambient room air. For purposes of this presentation, the term "air" is used for any effluent from the equipment.

\footnotetext{
1 Bird Corp., Palm Springs, Calif.

2 Bennett Respiration Products, Los Angeles, Calif.

3 Duncan Oxygen Therapy Co., Duncan, Okla.

4 Puritan Compressed Gas Corp., Kansas City, Mo.

5 Mistogen Equipment Co., Oakland, Calif.
} 
Sampling methodology. The air sampler employed was an Anderson model 0604 (6). The sampling rate varied between 15 and $22 \mathrm{~L}$ of air per minute. This sampler is capable of sorting viable airborne particles into six size ranges and enables determination of the number of viable particles in the volume of air sampled in each size range up to a maximum of 2,500 particles. All of the results refer to the number of particles of 1.4to $3.5-\mu$ size (stage 5 of this sampler).

One-minute ambient air samples were collected at the beginning and end of each sampling period. The intermittent positive pressure breathing machines (IPPB) were set at 15 to $20 \mathrm{~cm}$ water pressure, and the flow rate of the Bird machines was set to match the pressure. The flow rate of the nebulizer was adjusted to 5 to $8 \mathrm{~L}$ per minute. Each machine was manually cycled eight times in a 30 -second interval (to simulate a normal respiratory rate) while the air sampler was running. Reservoir nebulizers used independently of IPPB machines were sampled for 30 seconds at an oxygen flow of 5 to $8 \mathrm{~L}$ per minute with the air mix venturi set at $40 \%$ oxygen. The distance between the mouthpiece of machines and the air sampler intake orifice was 1 to 2 $\mathrm{cm}$. At the conclusion of each sample, the air sampler was allowed to "flush" for an additional 30 seconds with room air. All results were converted to viable particle counts per $7.5 \mathrm{~L}$ of effluent, since this corresponds to a normal minute ventilation.

Reservoir mainstream nebulizers had quantitative bacteriologic assays of the fluid contained within the nebulizer jars. Such fluid consisted of distilled water, saline, detergents, propylene glycol, or various combinations of these agents.

Microbiologic methodology. Air samples were collected on trypticase soy agar ${ }^{6}$ containing 1.5 to $2 \%$ agar. Each Andersen glass Petri dish, especially modified for the air sampler, contained 26 to $28 \mathrm{ml}$ of this media. The reservoir nebulizer fluid was diluted 1:100 with sterile saline, and $0.1 \mathrm{ml}$ was immediately incorporated into $1 \%$ trypticase soy agar. Plates were incubated at $37 \mathrm{C}$, and viable particle counts were made at 48 hours. The counts were not corrected by subtraction of the ambient air count. Representative colonies from each plate were subcultured onto eosin methylene blue agar, ${ }^{7}$ $5 \%$ sheep blood agar, and subsequently identified according to standard bacteriological techniques.

The reservoir nebulizer jars of three "clean". IPPB machines were filled with solutions containing viable Staphylococcus aureus 502A.8 It is coagulase-positive, hemolytic, and pigmented; however, it does not produce penicillinase and is essentially nonvirulent for man $(7,8)$. Flasks containing $50 \mathrm{ml}$ of trypticase soy broth were inoculated, incubated with shaking at $37^{\circ} \mathrm{C}$ for 18 hours, then emptied into sterile reservoir nebulizer jars and diluted to $500 \mathrm{ml}$ with sterile distilled water. The bacterial

${ }^{6}$ Baltimore Biological Laboratory, Baltimore, Md.

7 Difco Laboratories, Detroit; Mich.

8 Obtained from Dr. H. F. Eichenwald. solutions were nebulized for 5 minutes to accomplish inoculation of the nebulizer jet and distal components. Sampling was then carried out in the standard way. The reservoir nebulizer jars containing the cultures were removed and replaced with sterile jars containing sterile distilled water. The machines were then nebulized for 5 minutes, and sampling was repeated immediately and at 8,24 , and 48 hours. The bacteria isolated were quantitated and identified.

Hospitals. Sampling was performed at Parkland Memorial Hospital and five additional major hospitals. Three of these are institutions with predominantly private patients. Equipment was studied before, after, or during patient treatments with no effort made to select apparatus for study that appeared either "clean" or "dirty."

Standard cleaning practices at Parkland Memorial Hospital consist of disassembly of plastic tubing, exhalation valve, medication nebulizer, and mainstream reservoir nebulizer. These are brushed with soap and water, rinsed, and immersed in a $1 \%$ phenolic disinfectant solution for 15 minutes. The units are then rinsed with tap water, dried, and packaged for reissue. Comparable procedures are employed at other hospitals.

\section{Results}

Prevalence and degree of contamination. In 78 of 100 samples the number of viable $1.4-$ to $3.5-\mu$ particles in room air did not exceed 5 per $7.5 \mathrm{~L}$ of air, and in only 11 samples were there greater than 10 viable particles per $7.5 \mathrm{~L}$. These figures are comparable to quantitative air counts reported in other hospitals in the United States (9).

A total of 52 IPPB machines without mainstream reservoir nebulizers was sampled at six hospitals. In no instance did aerosols contain greater than 5 viable particles per sample. Thus, machines that were not equipped with reservoir nebulizers did not generate aerosols with significant bacterial contamination.

The majority of equipment with reservoir nebulizer assemblies generated aerosols containing large numbers of viable bacteria (Table I). Only $16 \%$ generated aerosols with viable particle counts as low as those in ambient air, whereas $45 \%$ generated greater than 2,500 viable particles of the 1.4to $3.5-\mu$ size per $7.5 \mathrm{~L}$ of air. The prevalence and degree of contamination were similar in each hospital. Specifically, $85 \%$ of equipment in hospital A generated aerosols with bacterial counts greater than ambient air, compared to $81 \%$ in hospital B, $80 \%$ in hospital C, $75 \%$ in hospital $\mathrm{D}$, and $91 \%$ in hospital $\mathrm{F}$.

Determination of site of contamination. The 
TABLE I

Detection of viable bacteria in aerosols generated by inhalation therapy equipment

\begin{tabular}{|c|c|c|c|c|c|c|c|c|}
\hline \multirow[b]{2}{*}{ Type of equipment } & \multirow[b]{2}{*}{$\begin{array}{l}\text { Bacterial } \\
\text { counts* }\end{array}$} & \multicolumn{7}{|c|}{$\begin{array}{l}\text { Number of machines sampled } \\
\text { at separate hospitalst }\end{array}$} \\
\hline & & $\mathbf{A}$ & B & C & D & $\mathbf{F}$ & $\begin{array}{l}\text { To } \\
\text { No. }\end{array}$ & tal \\
\hline \multirow{3}{*}{$\begin{array}{l}\text { Bennett with mainstream } \\
\text { reservoir nebulizer }\end{array}$} & $>2,500$ & 27 & & 0 & & 5 & 32 & 53 \\
\hline & $5-2,500$ & 8 & & 5 & & 10 & 23 & 39 \\
\hline & $<5$ & 3 & & 1 & & 1 & 5 & 8 \\
\hline \multirow{3}{*}{$\begin{array}{l}\text { Bird with mainstream } \\
\text { reservoir nebulizer }\end{array}$} & $>2,500$ & 25 & 6 & & 1 & & 32 & 38 \\
\hline & $5-2,500$ & 13 & 16 & & 6 & & 35 & 41 \\
\hline & $<5$ & 9 & 5 & & 4 & & 18 & 21 \\
\hline \multirow[t]{3}{*}{ Puritan nebulizer } & $>2,500$ & 6 & & 2 & 2 & 4 & 14 & 48 \\
\hline & $5-2,500$ & 5 & & 1 & 3 & 1 & 10 & 34 \\
\hline & $<5$ & 3 & & 1 & $\mathbf{0}$ & 1 & 5 & 17 \\
\hline \multirow[t]{3}{*}{ Subtotal } & $>2,500$ & 58 & 6 & 2 & 3 & 9 & 78 & 45 \\
\hline & $5-2,500$ & 26 & 16 & 6 & 9 & 11 & 68 & 39 \\
\hline & $<5$ & 15 & 5 & 2 & 4 & 2 & 28 & 16 \\
\hline Total & & 99 & 27 & 10 & 16 & 22 & 174 & 100 \\
\hline
\end{tabular}

* Bacterial counts expressed as number of viable 1.4- to 3.5- $\mu$ particles per 7.5 L of air.

+ Each count represents one sampling period for one apparatus. At hospich count repres hospital A a total of 22 Bennett and 18 Bird IPPB (intermittent posipiece of equipment was sampled only once.

Bennett and Bird respirators with mainstream reservoir nebulizers were otherwise structurally similar to those without mainstream reservoir nebulizers. Hence, the striking differences observed between equipment containing reservoir nebulization assemblies and equipment containing only a medication nebulizer suggested that contamination related to the reservoir nebulizer. Machines were therefore disassembled and sampled

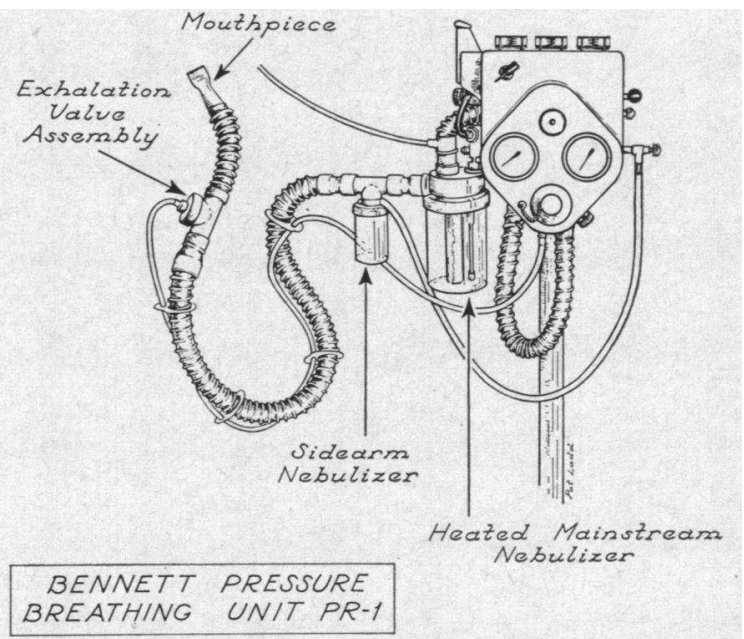

Fig. 1. Diagram of Representative intermittent POSITIVE PRESSURE MACHINE ILLUSTRATING MODEL WITH RESERVOIR NEBULIZER ASSEMBLY. The sidearm nebulizer is the medication nebulizer, and the heated mainstream nebulizer is the reservoir nebulizer. Sequential disassembly was accomplished by disconnection of tubing at the sites under question.

to determine the proximal site of contamination (Figure 1). The major site of generation of bacterial aerosols was the reservoir nebulizer (Table II).

The types of organisms isolated from the nebulizer fluid and from air samples from the equipment were correlated. Correlation was considered "good" when either all organisms or the predominant organisms were identical both in the

TABLE II

Detection of site of bacterial contamination based upon sequential disassembly of IPPB machines

\begin{tabular}{|c|c|c|c|c|}
\hline \multirow[b]{2}{*}{$\underset{\text { no.* }}{\text { Machine }}$} & \multicolumn{4}{|c|}{ Bacterial counts at sequential sampling sites $\dagger$} \\
\hline & Mouthpiece & $\begin{array}{c}\text { After } \\
\text { medication } \\
\text { nebulizer }\end{array}$ & $\begin{array}{c}\text { After } \\
\text { reservoir } \\
\text { nebulizer }\end{array}$ & $\begin{array}{c}\text { Before } \\
\text { reservoir } \\
\text { nebulizer }\end{array}$ \\
\hline $\begin{array}{r}1 \\
2 \\
3 \\
4 \\
5 \\
6 \\
7 \\
8 \\
9 \\
10 \\
11 \\
12 \\
13 \\
14\end{array}$ & $\begin{array}{r}194 \\
221 \\
>2,500 \\
>2,500 \\
>2,500 \\
>2,500 \\
>2,500 \\
>2,500 \\
>2,500 \\
>2,500 \\
45 \\
>2,500 \\
>2,500 \\
>2,500\end{array}$ & $\begin{array}{r}555 \\
243 \\
>2,500 \\
>2,500 \\
>2,500 \\
>2,500 \\
>2,500 \\
>2,500 \\
130 \\
>2,500 \\
64 \\
122 \\
>2,500 \\
>2,500\end{array}$ & $\begin{array}{r}>2,500 \\
388 \\
>2,500 \\
>2,500 \\
>2,500 \\
>2,500 \\
>2,500 \\
>2,500 \\
>2,500 \\
>2,500 \\
41 \\
50 \\
>2,500 \\
>2,500\end{array}$ & $\begin{array}{r}2 \\
5 \\
14 \\
138 \\
3 \\
3 \\
1 \\
0 \\
59 \\
12 \\
1 \\
0 \\
5 \\
1\end{array}$ \\
\hline
\end{tabular}

* Samples obtained from nine Bird respirators and five Bennett respirators.

$\dagger$ Bacterial counts expressed as number of viable 1.4- to $3.5-\mu$ particles per $7.5 \mathrm{~L}$ of air. 


\section{CORRELATION OF VIABLE PARTICLE COUNTS FROM AIR AND COLONY COUNTS FROM NEBULIZER*}

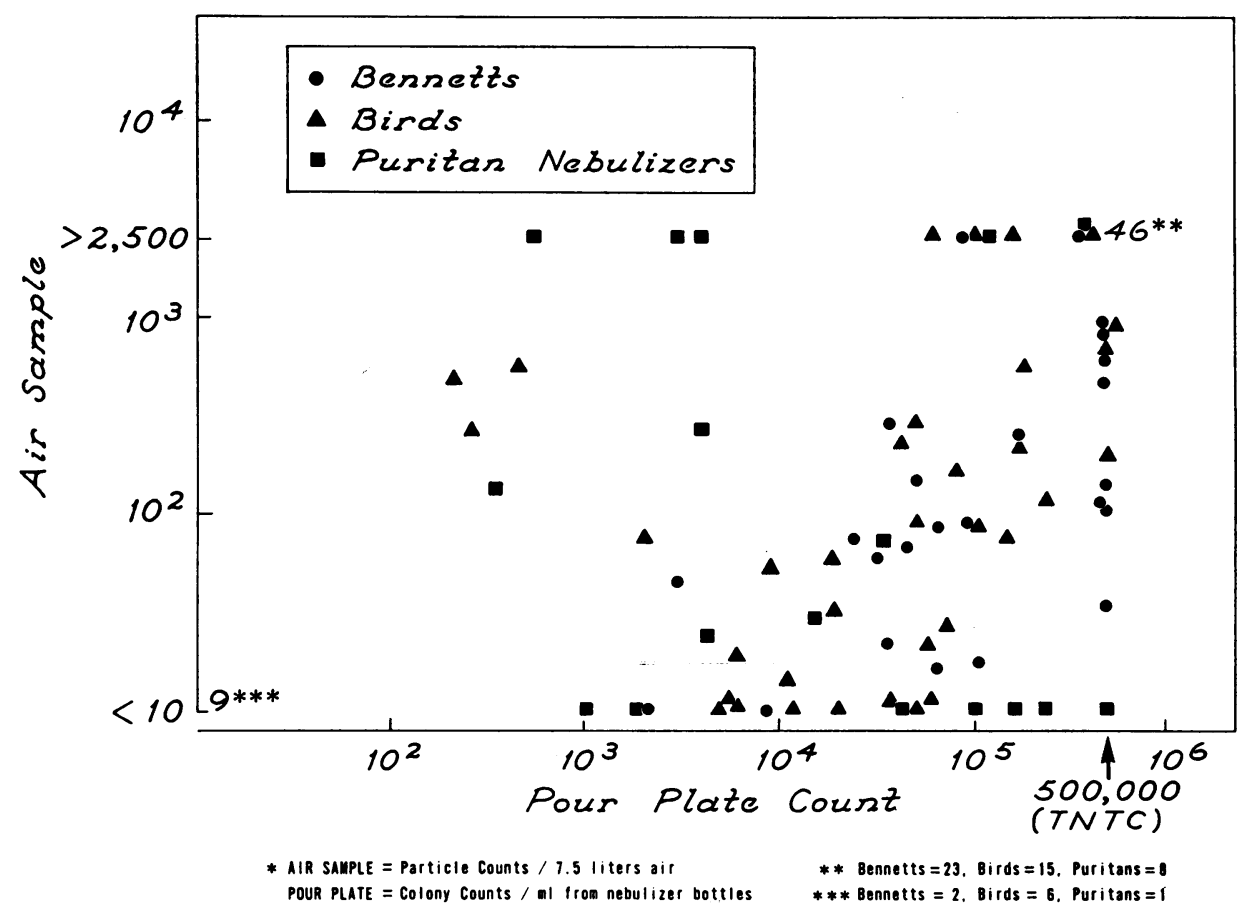

Fig. 2. Correlation of viable particle counts from aIR aNd bacterial counts on NEBULIZER FLUID. Air sample represents viable particle counts of $1.4-$ to $3.5-\mu$ size per $7.5 \mathrm{~L}$ of air. Pour-plate count depicts number of viable units per $\mathrm{ml}$ of nebulizer fluid. TNTC= too numerous to count.

reservoir fluid and in the air samples. This occurred in 66 of 82 samples $(81 \%)$. Correlation was considered "fair" when at least one organism was common to both sites, 8 of 82 samples (9\%). No correlation existed when different organisms were isolated from the two sites, 8 of 82 samples (9\%). These levels of correlation held with dif-

TABLE III

Appearance of contaminated aerosols in "clean" IPPB machines not used in patient care

\begin{tabular}{crrr}
\hline \hline \multirow{2}{*}{$\begin{array}{c}\text { Machine } \\
\text { no.* }\end{array}$} & \multicolumn{3}{c}{ Bacterial counts at sequential time intervals $\dagger$} \\
\cline { 2 - 4 } & 0 hour & $12-18$ hours & 24-36 hours \\
\hline 1 & 27 & 49 & 72 \\
2 & $>2,500$ & $>2,500$ & $>2,500$ \\
3 & 1 & 8 & 88 \\
4 & 2 & $>2,500$ & 172 \\
5 & 230 & $>2,500$ & $>2,500$ \\
6 & & 102 & $>2,500$
\end{tabular}

* Samples obtained from four Bird respirators and two Bennett respirators.

$\dagger$ Bacterial counts expressed as number of viable 1.4- to 3.5- $\mu$ particles per $7.5 \mathrm{~L}$ of air. fering types of equipment and in separate hospitals. Correlation of bacterial numbers between air samples and nebulizer fluid was also apparent (Figure 2).

To determine the site of contamination in the reservoir nebulizer, several sets of studies were performed. In one group of IPPB machines with mainstream reservoir nebulizers, the generated aerosol was sampled, and the reservoir nebulizer was then emptied, rinsed thoroughly with tap water, and refilled with either sterile distilled water or tap water. Each machine was then cycled for 5 minutes, and the aerosol was again sampled. The rinsing and change to clean water usually diminished the viable particle count of the aerosols, but did not reduce counts to those of ambient air. This was usually maintained for 8 hours, but after 24 hours bacterial counts approximated original prerinse numbers.

Subsequently, sterile reservoir nebulizer jars on 6 "clean" IPPB machines were filled aseptically 
TABLE IV

Types of microorganisms isolated from inhalation therapy equipment at separate hospitals

\begin{tabular}{|c|c|c|c|c|c|c|c|c|c|c|c|c|c|}
\hline \multirow[b]{2}{*}{$\begin{array}{l}\text { Hos- } \\
\text { pital }\end{array}$} & \multirow[b]{2}{*}{$\begin{array}{l}\text { Source of } \\
\text { sample }\end{array}$} & \multirow[b]{2}{*}{$\begin{array}{l}\text { No. of } \\
\text { positive } \\
\text { samples }\end{array}$} & \multicolumn{11}{|c|}{ Bacterial species (no. of isolates)* } \\
\hline & & & $\begin{array}{l}\text { Pseudo. } \\
\text { sp. }\end{array}$ & $\begin{array}{c}\text { Flavo. } \\
\text { sp. }\end{array}$ & $\begin{array}{c}\text { Herellea } \\
\text { sp. }\end{array}$ & $\begin{array}{c}\text { Alc. } \\
\text { fecalis }\end{array}$ & $\begin{array}{c}\text { Achromo. } \\
\text { sp. }\end{array}$ & $\begin{array}{c}\text { Mima } \\
\text { sp. }\end{array}$ & $\begin{array}{c}\text { Ser- } \\
\text { ratia } \\
\text { sp. }\end{array}$ & $\begin{array}{l}A l . \\
\text { sp. }\end{array}$ & $\underset{\text { inter. }}{E .}$ & $\begin{array}{l}\text { Aero. } \\
\text { aerog. }\end{array}$ & $\begin{array}{l}\text { Prevalent } \\
\text { organism } \dagger\end{array}$ \\
\hline \multirow[t]{2}{*}{ A } & $\begin{array}{l}\text { Aerosol } \\
\text { Nebulizer }\end{array}$ & 62 & 32 & 12 & 20 & 27 & 15 & 3 & 1 & $\mathbf{0}$ & 1 & 4 & Pseudo. sp. \\
\hline & fluid & 44 & 21 & 7 & 5 & 22 & 5 & 3 & 1 & $\mathbf{0}$ & 0 & 4 & \\
\hline \multirow[t]{2}{*}{ B } & $\begin{array}{l}\text { Aerosol } \\
\text { Nebulizer }\end{array}$ & 20 & 4 & 15 & 2 & 9 & 4 & 1 & 0 & 0 & 0 & 0 & Flavo. sp. \\
\hline & fluid & 22 & 9 & 12 & 0 & 5 & 1 & 2 & 0 & 1 & $\mathbf{0}$ & 0 & \\
\hline \multirow[t]{2}{*}{$\mathrm{C}$} & $\begin{array}{l}\text { Aerosol } \\
\text { Nebulizer }\end{array}$ & 6 & 3 & 2 & 0 & 1 & 1 & 0 & 0 & 1 & $\mathbf{0}$ & 0 & Pseudo. sp. \\
\hline & fluid & 7 & 4 & 2 & $\mathbf{0}$ & 2 & 1 & 1 & 0 & 0 & $\mathbf{0}$ & 0 & \\
\hline \multirow[t]{2}{*}{$\mathrm{D}$} & $\begin{array}{l}\text { Aerosol } \\
\text { Nebulizer }\end{array}$ & 13 & 3 & 2 & 11 & 1 & 2 & 3 & $\mathbf{0}$ & $\mathbf{0}$ & 0 & 0 & Herellea sp. \\
\hline & fluid & 9 & 1 & 2 & 8 & 1 & 1 & 0 & 0 & 0 & 0 & 0 & \\
\hline \multirow[t]{2}{*}{$F$} & $\begin{array}{l}\text { Aerosol } \\
\text { Nebulizer }\end{array}$ & 20 & $18 t$ & 5 & 0 & 2 & 0 & 1 & 0 & 1 & 0 & 0 & Pseudo. sp. $\ddagger$ \\
\hline & fluid & 19 & $18 \ddagger$ & 1 & 0 & 0 & 0 & 0 & 0 & 1 & 0 & 0 & \\
\hline
\end{tabular}

* Abbreviations as follows: Pseudo. sp. = Pseudomonas species; Flavo. sp. = Flavobacterium species; Alc. = Alcaligenes; Achromo. sp. $=$ Achro mobacter species; Al. sp. = Alcaligenes species; $E$. inter. $=$ Escherichia intermedium; Aero. aerog. = Aerobacter aerogenes.

$t$ Prevalent organism refers to frequency of isolation. In most hospitals the prevalent isolates also were the predominant organisms isolated.

¥ These organisms were not typical Pseudomonas species. Isolates were studied at the Communicable Disease Center, Atlanta, Ga., and reported as Pseudomonas species. Isolates studied by Dr. S. G. Carey at Walter Reed Army Institute of Research were considered to closely resemble Cytophaga johnsonae.

with sterile distilled water. The machines were cycled for 30 minutes, and the aerosol was then sampled (Table III). These machines were maintained in a relatively bacteria-free environment and were not utilized in the care of patients. The only use was at the time of sampling. Exogenous contamination from patient sources was therefore excluded. Two machines immediately generated bacterial aerosols. After 12 to 18 hours, three additional machines yielded significant aerosols, and after 24 to 36 hours, all of the machines generated significant bacterial aerosols.

Types of microorganisms isolated from inhalation equipment. A large number of different species of bacteria were isolated from the various equipment (Table IV). Multiple species of organisms were isolated more commonly than a single species. The major contaminants were all gram-negative bacilli : Pseudomonas species, Flavobacteria species, Herellea species, Alcaligenes fecalis, and Achromobacter species. In no samples were gram-positive organisms isolated.

Evaluation of acetic acid as a means of elimination of bacterial aerosols. The standard cleaning procedures established for equipment with reservoir nebulizers are inadequate. It seemed reasonable to decontaminate the reservoir nebulizers jet by nebulizing antibacterial agents. Acetic acid at a concentration of $0.25 \%$ was chosen because it is an effective bacteriostatic agent and is easily available, inexpensive, and safe. To test the effectiveness of acetic acid, aerosols were sampled, and reservoir nebulizer jars were removed, rinsed with tap water, and refilled with $0.25 \%$ acetic acid. This solution was then nebulized for 5 minutes. The reservoir nebulizer jar was then removed, rinsed, and refilled with tap water that was nebulized for 5 minutes to remove residual acetic acid. This procedure was repeated daily. After the initial 5 minutes of acetic acid nebulization, bacterial contamination was reduced to that approximating ambient air (Table V). Twenty-four hours following a single 5-minute period of acetic acid nebulization, some increase in viable particles occurred. However, in samples obtained immediately before the subsequent daily 5 -minute nebulization, the number of viable particles remained at levels comparable to ambient air. Organisms apparently resistant to acetic acid were not encountered.

Persistence of Staphylococcus aureus, strain $502 \mathrm{~A}$, following massive contamination of reservoir nebulizer. The reservoir nebulizer jars of three IPPB machines were filled with cultures of viable Staphylococcus aureus 502A. The number of organisms varied from $1.3 \times 10^{9}$ to $2.5 \times 10^{\circ}$ 
TABLE V

Evaluation of acetic acid nebulization as a means of elimination of bacterial aerosols*

\begin{tabular}{|c|c|c|c|c|c|c|c|c|}
\hline \multirow[b]{2}{*}{ Type of equipment } & \multirow[b]{2}{*}{$\begin{array}{c}\text { Machine } \\
\text { no. }\end{array}$} & \multicolumn{7}{|c|}{ Bacterial counts at sequential time intervals $\dagger$} \\
\hline & & $\begin{array}{l}\text { Before } \\
\text { cleaning }\end{array}$ & $\begin{array}{c}0 \\
\text { hour }\end{array}$ & $\begin{array}{c}24 \\
\text { hours }\end{array}$ & $\begin{array}{c}48 \\
\text { hours }\end{array}$ & $\begin{array}{c}72 \\
\text { hours }\end{array}$ & $\begin{array}{l}96 \\
\text { hours }\end{array}$ & $\begin{array}{c}120 \\
\text { hours }\end{array}$ \\
\hline $\begin{array}{l}\text { Bennett with } \\
\text { reservoir nebulizer }\end{array}$ & $\begin{array}{r}1 \\
2 \\
3 \\
4 \\
5 \\
6 \\
7 \\
8 \\
9 \\
10 \\
11 \\
12 \\
13 \\
14 \\
15\end{array}$ & $\begin{array}{r}>2,500 \\
>2,500 \\
>2,500 \\
>2,500 \\
443 \\
>2,500 \\
>2,500 \\
>2,500 \\
>2,500 \\
>2,500 \\
>2,500 \\
>2,500 \\
>2,500 \\
>2,500 \\
886\end{array}$ & $\begin{array}{r}12 \\
4 \\
5 \\
12 \\
3\end{array}$ & $\begin{array}{r}28 \\
30 \\
21 \\
5 \\
19 \\
23 \\
19 \\
8 \\
7 \\
5 \\
47 \\
1 \\
17 \\
72 \\
19\end{array}$ & $\begin{array}{r}8 \\
5 \\
4 \\
7 \\
2 \\
8 \\
16 \\
9 \\
7 \\
3\end{array}$ & $\begin{array}{l}5 \\
0 \\
1 \\
1 \\
4 \\
7 \\
6 \\
1 \\
1 \\
3\end{array}$ & $\begin{array}{l}3 \\
0 \\
6 \\
1 \\
7 \\
1 \\
0 \\
1 \\
2 \\
1\end{array}$ & $\begin{array}{l}4 \\
2 \\
5 \\
3 \\
2\end{array}$ \\
\hline
\end{tabular}

* The reservoir nebulizer jar was rinsed with tap water, then refilled with $0.25 \%$ acetic acid. The nebulizer was run for 5 minutes; then the jar was emptied and refilled with tap water. Equipment was maintained in patient use during study. Bacterial counts were obtained before daily nebulization of acetic acid.

$\dagger$ Bacterial counts expressed as number of viable 1.4- to 3.5- $\mu$ particles per $7.5 \mathrm{~L}$ of air.

viable units per $\mathrm{ml}$. Immediately after a 5-minute interval of nebulization the generated aerosols contained massive numbers of the test organism (Table VI). Even after flushing with sterile distilled water, viable staphylococci in the generated aerosols were still too numerous to count. After 8 hours, species of gram-negative bacilli were isolated from the aerosols generated by each of the machines. Furthermore, staphylococci had virtually disappeared from two of the three machines (sample 2). By 24 hours, staphylococci were no longer isolated, but in contrast large numbers of gram-negative bacilli were isolated (samples 3 and 4). The effect of acetic acid nebulization was similar to that previously recorded (samples 5 and 6).

\section{Discussion}

The foregoing observations demonstrate that inhalation therapy equipment frequently generates significant bacterial aerosols. To evaluate the potential pathogenicity of these aerosols, several factors must be considered. Organisms must not

TABLE VI

Persistence of Staphylococcus aureus following massive contamination of reservoir nebulizer

\begin{tabular}{|c|c|c|c|c|c|c|c|}
\hline \multirow{2}{*}{$\begin{array}{c}\text { Sample } \\
\text { no. }\end{array}$} & \multirow[b]{2}{*}{ Time of sample } & \multicolumn{2}{|c|}{ Machine no. 1} & \multicolumn{2}{|c|}{ Machine no. 2} & \multicolumn{2}{|c|}{ Machine no. 3} \\
\hline & & Organisms & Counts* & Organisms & Counts & Organisms & Counts \\
\hline $\begin{array}{l}1 \\
2\end{array}$ & $\begin{array}{l}0 \text { hour } \\
8 \text { hours }\end{array}$ & $\begin{array}{l}\mathrm{C}+\mathrm{S} \dagger \\
\mathrm{C}+\mathrm{S}\end{array}$ & $\begin{array}{r}>2,500 \\
157\end{array}$ & $\begin{array}{l}\mathrm{C}+\mathrm{S} \\
\text { Achromobacter }\end{array}$ & $\begin{array}{l}>2,500 \\
>2,500\end{array}$ & $\begin{array}{l}\mathrm{C}+\mathrm{S} \\
\mathrm{C}+\mathrm{S}\end{array}$ & $\begin{array}{l}>2,500 \\
>2,500\end{array}$ \\
\hline 3 & 24 hours & $\begin{array}{l}\text { Flavobacterium } \\
\text { Herellea }\end{array}$ & $\begin{array}{l}198 \\
225\end{array}$ & $\begin{array}{l}\text { Alc. fecalis } \\
\text { Achromobacter } \\
\text { Flavobacterium }\end{array}$ & $\begin{array}{r}03 \\
277 \\
555 \\
14\end{array}$ & $\begin{array}{l}\text { Alc.fecalis } \\
\text { Herellea }\end{array}$ & $\begin{array}{l}>2,500 \\
>2,500\end{array}$ \\
\hline 4 & 48 hours & $\begin{array}{l}\text { Alc. fecalis } \\
\text { Flavobacterium } \\
\text { Herellea }\end{array}$ & $\begin{array}{r}71 \\
99 \\
>2,500\end{array}$ & $\begin{array}{l}\text { Alc. fecalis } \\
\text { Achromobacter }\end{array}$ & $\begin{array}{l}14 \\
277 \\
555\end{array}$ & $\begin{array}{l}\text { Alc. fecalis } \\
\text { Herellea }\end{array}$ & $\begin{array}{l}>2,500 \\
>2,500\end{array}$ \\
\hline 5 & $\begin{array}{l}48 \text { hours repeated after } \\
\text { flushing with acetic } \\
\text { acid }\end{array}$ & Not identified & 1 & Not identified & 2 & Not identified & 1 \\
\hline 6 & 24 hours after sample 5 & $\begin{array}{l}\text { Herellea } \\
\text { Achromobacter }\end{array}$ & $\begin{array}{r}47 \\
2\end{array}$ & Not identified & 1 & $\begin{array}{l}\text { Herellea } \\
\text { Achromobacter }\end{array}$ & $\begin{array}{r}14 \\
3\end{array}$ \\
\hline
\end{tabular}

* Bacterial counts expressed as number of viable 1.4- to 3.5- $\mu$ particles per 7.5 L of air.

$+\mathrm{C}+\mathrm{S}=$ coagulase-positive staphylococcus. 
only be identified and quantitated; they also must be differentiated as to the particle size of the aerosol in which they are generated. Studies on the infectivity of aerosols have shown that minimal infectious dose of a number of pathogenic bacteria and viruses is less if delivered in aerosols of a size capable of deposition beyond the level of ciliated epithelium (10). It has been estimated that at least $50 \%$ of 1.0 - to $2.0-\mu$ particles, when delivered to the mouth or nose of an individual, are capable of entering the bronchial tree distal to the terminal bronchioles $(11,12)$. Therefore, aerosolized particles of this size range (1.4- to $3.5-\mu$ ) were selected for study. Since only a portion of the bacteria is suspended in 1.4- to 3.5-u aerosols, these estimates represent only a fraction of the total bacteria capable of deposition in the tracheobronchial tree.

The respirator machine itself, tubing, exhalation valve assemblies, and sidearm (medication) nebulizers are identical in respirators both with and without mainstream reservoir nebulizers, yet contaminated aerosols were never obtained from respirators without mainstream reservoir nebulizers. Thus, respirators without mainstream reservoir nebulizers impose no greater risk to a patient than that imposed by breathing room air. This is also true of other inhalation equipment not incorporating nebulization assemblies, e.g., humidifiers, anesthesia machines, and pediatric isolettes.

That the reservoir nebulizer is the major source of difficulty was based upon the following observations. First, equipment without reservoir nebulizers did not generate significant bacterial aerosols. Second, sequential disassembly of apparatus with reservoir nebulizers demonstrated bacterial aerosols distal but not proximal to the reservoir nebulizer. Third, there was correlation of both numbers and species of organisms in the generated aerosols and the reservoir nebulizer fluid.

The reservoir nebulizer jet is encased in a housing that is not routinely disassembled for cleaning and may not be reached by disinfectants. The nebulizer jet appears to serve as a nidus to contaminate the reservoir nebulizer fluid. A vicious cycle thus may be initiated in which the nebulizer jet not only nebulizes particles directly into the aerosol, but also serves to inoculate fresh reservoir fluid in which bacteria may propagate. The secondary survival and propagation of organisms in reservoir nebulizer fluids then serves as the major source of organisms generated in the aerosols.

The organisms isolated are quite stable in humid environments, and a wide range of temperatures will support their growth (13-15). Gram-positive bacteria-Staphylococcus aureus, Streptococcus pyogenes, and Diplococcus pneumoniae-were conspicuous by their absence. Certainly no lack of opportunity existed for contamination, since several patients had staphylococcal pneumonia at the time inhalation therapy was instituted. Moreover, in the IPPB machines, which were massively contaminated with Staphylococcus aureus, these organisms could not be recovered from the aerosols at 24 hours. This was not unexpected, as McDade and Hall have shown that the survival of strains of Staphylococcus aureus was diminished at high relative humidity (16). It is of additional interest that the staphylococci were supplanted by species of gramnegative bacilli.

The problem is obviously of greater significance if demonstrable in various hospitals that differ in organization of inhalation therapy services, in utilization of equipment, and in cleaning techniques, as well as in types of patients. Comparable machines were comparably contaminated regardless of the hospital in which they were located. The prevalence of contamination is determined by the equipment design. Whereas it can be stated that certain equipment will be contaminated, it cannot be predicted which gramnegative organisms will be the contaminants. The flora varies among hospitals, but is relatively constant within the same hospital.

The significance of these observations in the pathogenesis of acute gram-negative bacillary necrotizing pneumonias gains support from at least three series of observations. First, a tenfold increase in frequency of occurrence of this syndrome has been observed at Parkland Memorial Hospital (5). This increase has been associated with the concomitant introduction and widespread utilization of inhalation therapy equipment incorporating reservoir nebulization. During this interval 
other potential factors have been introduced; however, the association with factors such as broadspectrum antibiotics or corticosteroids was not good. Final epidemiologic support of the association will depend upon the decontamination of equipment and the subsequent observation of a decrease in frequency of development of these gram-negative bacillary pneumonias. Second, we have followed individual patients admitted with pulmonary disorders requiring continued ventilatory assistance who subsequently have developed extensive pneumonitis and empyema due to organisms such as Herellea species. Such gramnegative bacilli were isolated initially from aerosols generated by the IPPB machines used on the patient. At post-mortem, the same species of gram-negative bacilli have been isolated from the pneumonic areas of lung in quantities of greater than $10^{6}$ organisms per gram of lung. Third, Pseudomonas species, Herellea species, and Achromobacter species have been incriminated as causes of lobar pneumonia, bronchopneumonia, lung abscess, and necrotizing pneumonia $(15,17-$ 24). These observations suggest that inhalation therapy involving reservoir nebulization may be analogous to the urethral catheter as a source of nosocomial infection. This role has been virtually ignored (25-29).

Acetic acid in a concentration of $0.25 \%$ was found to give satisfactory antibacterial activity in this study. Parker and Hoeprich performed sensitivity determinations with $0.25 \%$ acetic acid against Escherichia coli, Klebsiella, enterococci, Staphylococcus aureus, Pseudomonas, and Proteus species (30). Although acetic acid was bactericidal for only 49 of 149 strains that were tested by Parker and Hoeprich, resistant organisms were not encountered in our study, and in every instance the equipment was rendered virtually sterile.

Finally, it should be emphasized that although inhalation therapy equipment which incorporates reservoir nebulization into its design constitutes a potential hazard, the use of inhalation therapy equipment without mainstream reservoir nebulizers or with decontaminated reservoir nebulizers poses no greater hazard than breathing ambient hospital air. These observations should not be construed as a condemnation of inhalation therapy, which clearly constitutes an important facet of care in many bronchopulmonary disorders. Rather, they indicate the need for continued surveillance of hospital procedures if nosocomial infections are to be detected, epidemiology defined, and control implemented.

\section{Summary}

1. Most inhalation therapy equipment incorporating reservoir nebulizers has been shown to generate aerosols containing large numbers of viable bacteria. The aerosols are of a size capable of penetration beyond the level of ciliated bronchial epithelium.

2. The source of bacterial aerosols is the reservoir nebulizer jet, which is not decontaminated by standard cleaning techniques. The jet serves as a nidus to inoculate the reservoir fluid in which the organisms propagate.

3. The specific organisms isolated from aerosols vary from institution to institution. The major contaminants are Pseudomonas species, Flavobacterium species, Herellea species, Alcaligenes species, and Achromobacter species. The particular bacterial species is hospital dependent. Only gram-negative organisms have been isolated.

4. These contaminants are not benign commensals, and a causal relationship is suggested between gram-negative bacillary necrotizing pneumonia and inhalation therapy equipment utilizing reservoir nebulization.

5. Equipment without reservoir nebulizers does not generate aerosols containing numbers of bacteria in excess of numbers of bacteria in ambient air.

6. Brief daily nebulization of $0.25 \%$ acetic acid affords a simple and effective means for the decontamination of inhalation therapy equipment with reservoir nebulizers.

\section{Addendum}

In initial studies, equipment that could not be decontaminated to a level comparable to ambient air was not encountered. However, with implementation on a widescale basis, despite relative decontamination, as many as $19 \%$ of pieces of equipment sporadically demonstrated bacterial counts greater than ambient air despite $0.25 \%$ acetic acid nebulization. Studies are currently in progress to evaluate other decontamination regimens. 


\section{Acknowledgments}

The authors wish to express their appreciation to Drs. R. G. Loudon and H. Yeager, Jr., for their assistance in the design and initial phase of these studies. We wish to recognize the generosity of the hospital administrators and the inhalation therapy directors at each of the six hospitals for allowing us to sample equipment and for their assistance in facilitating the sampling. Also, we wish to express our appreciation to Carolyn Arnold for her inestimable assistance in the preparation of this manuscript.

\section{References}

1. Rogers, D. E. The changing pattern of life-threatening microbial disease. New Engl. J. Med. 1959, 261, 677.

2. Martin, C. M., F. Vaquer, M. S. Meyers, and A. ElDadah. Prevention of gram-negative rod bacteremia associated with indwelling urinary tract catheterization in Antimicrobial Agents and Chemotherapy-1963. Ann Arbor, Braun-Brumfield, 1964 p. 617.

3. Sanford, J. P. Hospital-acquired urinary-tract infections. Ann. intern. Med. 1964, 60, 903.

4. Lepper, M. H. Opportunistic gram-negative rod pulmonary infections. Dis. Chest 1963, 44, 18.

5. Pierce, A. K., E. B. Edmondson, W. G. McGee, and J. P. Sanford. Unpublished observations.

6. Andersen, A. A. New sampler for the collection, sizing, and enumeration of viable airborne particles. J. Bact. 1958, 76, 471.

7. Shinefield, H. R., J. C. Ribble, M. Boris, and H. F. Eichenwald. Bacterial interference: its effect on nursery-acquired infection with Staphylococcus aureus. I. Preliminary observations on artificial colonization of newborns. Amer. J. Dis. Child. 1963, 105, 646.

8. Shinefield, H. R., J. C. Ribble, H. F. Eichenwald, M. Boris, and J. M. Sutherland. Bacterial interference: its effect on nursery-acquired infections with Staphylococcus aureus. V. An analysis and interpretation. Amer. J. Dis. Child. 1963, 105, 683.

9. Green, V. W., D. Vesley, R. G. Bond, and G. S. Michaelsen. Microbiological contamination of hospital air. I. Quantitative studies. Appl. Microbiol. 1962, 10, 561.

10. Sawyer, W. D. Airborne infection. Milit. Med. 1963, 128, 90.

11. Weimer, J. T., T. A. Ballard, and C. L. Punte. Respiratory retention of one micron particles in man. Dis. Chest 1963, 44, 268.

12. Mitchell, R. I. Retention of aerosol particles in the respiratory tract. A review. Amer. Rev. resp. Dis. $1960,82,627$.

13. Wilson, G. S., and A. A. Miles, Eds. Topley and Wilson's Principles of Bacteriology and Immunology, 4th ed. Baltimore, Williams \& Wilkins, 1955, vol. 1, chap. 21 and 26.
14. Breed, R. S., E. G. D. Murray, and N. R. Smith. Bergey's Manual of Determinative Bacteriology, 7th ed. Baltimore, Williams \& Wilkins, 1957, p. 309.

15. Daly, A. K., B. Postic, and E. H. Kass. Infection due to organisms of the genus Herellea. B5W and B. Anitratum. Arch. intern. Med. 1962, 110, 580.

16. McDade, J. J., and L. B. Hall. Survival of Staphylococcus aureus in the environment. Exposure on surfaces. Amer. J. Hyg. 1963, 78, 330.

17. Forkner, C. E. Pseudomonas aeruginosa Infections. New York, Grune \& Stratton, 1960.

18. Sabath, L. D., B. Postic, and M. Finland. Methicillin treatment of severe staphylococcal disease. Observations in 146 cases. New Engl. J. Med. 1962, 267, 1049.

19. Reynolds, R. C., and L. E. Cluff. Infection of man with Mimae. Ann. intern. Med. 1963, 58, 759.

20. Robinson, R. G., R. G. Garrison, and R. W. Brown. Evaluation of the clinical significance of the genus Herellea. Ann. intern. Med. 1964, 60, 19.

21. Garrison, R. G. The occurrence of Bacterium anitratum in secretions of pulmonary origin. Amer. J. clin. Path. 1963, 40, 260.

22. Graber, C. D., I. R. Rabin, A. D. Mason, Jr., and E. H. Vogel, Jr. Increasing incidence of nosocomial Herellea vaginicola infections in burned patients. Surg. Gynec. Obstet. 1962, 114, 109.

23. Gardner, D. L., A. Pines, and S. M. Stewart. Fulminating and fatal pneumonia and septicaemia due to Achromobacter anitratus. Brit. med. J. 1960, 1,1108 .

24. Glich, L. M., G. P. Moran, J. M. Coleman, and G. F. O'Brien. Lobar pneumonia with bacteremia caused by Bacterium anitratum. Amer. J. Med. 1959, 27, 183.

25. Sever, J. L. Possible role of humidifying equipment in spread of infections from the newborn nursery. Pediatrics 1959, 24, 50.

26. Mortensen, J. D., G. Hurd, and G. Hill. Bacterial contamination of oxygen used clinically-importance and one method of control. Dis. Chest 1962, 42, 567.

27. Mortensen, J. D., and G. Hill. Clinical and bacteriologic evaluation of a new filter designed specifically for bacteriologic decontamination of oxygen used clinically. Dis. Chest 1964, 45, 508.

28. Baker, F. J., B. G. B. Lucas, and A. B. Selber. The sterility and sterilization of lung ventilators. Thorax 1963, 18, 313.

29. Kundsin, R. B., and C. W. Walter. Asepsis for inhalation therapy. Anesthesiology 1962, 23, 507.

30. Parker, R. W., and P. D. Hoeprich. In vitro effect of buffered solutions of acetic acid, triclobisonium chloride, chlorhexidine diacetate, and chlorhexidine digluconate on urinary tract infections in Antimicrobial Agents and Chemotherapy-1962. Ann Arbor, Braun-Brumfield, 1963, p. 26. 